\title{
STUDI LITERATUR PEMBELAJARAN INKUIRI TERBIMBING TERHADAP KEMAMPUAN BERPIKIR KRITIS IPA SMP
}

\author{
Herdianna Indawati ${ }^{1}$, Sarwanto ${ }^{2}$, dan Sukarmin ${ }^{3}$ \\ ${ }^{1}$ Program Studi Magister Pendidikan Sains, FKIP, Universitas Sebelas Maret \\ Surakarta, 57126, Indonesia \\ Email: ${ }^{1}$ herdianna12@ @student.uns.ac.id; ${ }^{2}$ sarwanto@fkip.uns.ac.id; ${ }^{3}$ sukarmin67@staff.uns.ac.id \\ Diajukan: 18 Agustus 2021; Diterima: 25 September 2021; Diterbitkan: 30 Oktober 2021
}

\begin{abstract}
Abstrak: Penelitian ini bertujuan guna mengkaji berbagai literatur mengenai model inkuiri terbimbing sebagai solusi guna tingkatkan keahlian berpikir kritis IPA SMP Negeri 4 Mojokerto. Bersumber pada hasil yang diperoleh dari hasil wawancara dengan guru, kemampuan berpikir kritis siswa masih terkategori rendah, dibuktikan dengan siswa yang pasif dalam memberikan jawaban dikala guru memberi pertanyaan. Masalah-masalah yang ada pada siswa membuat siswa menjadi kesulitan dalam menjelaskan uraian dasar, membangun keahlian dasar, merumuskan kesimpulan, membuat uraian lebih lanjut serta membuat strategi dan taktik, tidak hanya itu pada proses pembelajaran hanya mencermati penjelasan guru tanpa menghubungkan konsep-konsep yang dipelajari. Proses pembelajaran oleh guru sudah disesuaikan pada kurikulum 2013 yaitu pembelajaran discovery learning, namun pada kenyataannya guru hanya menjelaskan di depan kelas. Instrumen yang digunakan yaitu tes wawancara untuk guru dan siswa kelas delapan SMP Negeri 4 Mojokerto. Metode yang digunakan yaitu studi literatur dan wawancara. Berdasarkan hasil studi literatur diperlukan pemecahan guna mengatasi permasalahan tersebut dengan mempraktikkan model pembelajaran inkuiri terbimbing.
\end{abstract}

Kata Kunci: Model Pembelajaran Inkuiri Terbimbing, Berpikir Kritis, IPA

Abstract: This study aims to examine the literature on the guided inquiry model as a solution to improve science critical thinking skills at SMP Negeri 4 Mojokerto. Based on the results obtained from interviews with teachers, students' critical thinking skills are still categorized as low, as evidenced by students who are passive in providing answers when the teacher asks questions. The problems that exist in students make it difficult for students to explain basic descriptions, build basic skills, formulate conclusions, make further descriptions and make strategies and tactics, not only that in the learning process only pay attention to teacher explanations without connecting the concepts learned. The learning process by the teacher has been adjusted to the 2013 curriculum, namely discovery learning, but in reality the teacher only explains in front of the class. The instrument used was an interview test for teachers and eighth grade students of SMP Negeri 4 Mojokerto. The method used is literature study and interviews. Based on the results of the literature study, a solution is needed to overcome these problems by practicing the guided inquiry learning model.

Keywords: Guided Inquiry Learning Model, Critical Thinking, Science

\section{Pendahuluan}

Inkuiri yaitu runtutan usaha untuk memperoleh informasi melalui pengumpulan data terhadap suatu permasalahan. Pembelajaran inkuiri siswa dijadikan sebagai seorang ilmuan untuk melakukan eksperimen serta mampu melakukan proses mental untuk berinkuiri (Annafi et al., 2015). Inkuiri terbagi menjadi empat berdasarkan kompleksitas penerapannya yaitu inkuiri konfirmasi, inkuiri terstruktur, inkuiri terbimbing, dan inkuiri terbuka (Damhuri, 2020)

Keempat model pembelajaran inkuiri memiliki tahapan yang hampir sama, perbedaannya terletak pada peran siswa dan peran guru saat proses pembelajaran berjalan. Inkuiri terstrukur menempatkan siswa untuk membuat hipotesis dan melakukan eksperimen untuk menyatakan pembuktian dengan pemberian rumusan masalah dan prosedur yang diberikan oleh guru sebelumnya (Damhuri, 2020).

Model yang sesuai dengan siswa dalam kurangnya pengalaman belajar melalui proses penemuan yaitu dengan pemberian pembelajaran model inkuiri terbimbing. Siswa dituntut untuk menemukan konsep-konsep dari petunjuk yang didapat dari guru. Petunjuk tersebut berupa pertanyaan yang memiliki sifat untuk membimbing siswa dalam 
menyelesaikan permasalahan. Pemberian bimbingan diawal pembelajaran lebih banyak hingga akhirnya sedikit demi sedikit akan dikurangi dalam membimbing siswa. Sejalan dengan Hudoyono dalam Syamsu (2017) untuk menemukan konsep oleh siswa perlu adanya bimbingan guru langkah demi langkah. Dengan bimbingan guru siswa mampu mengembangkan kemampuannya dengan menghadapi kesulitan-kesulitan yang dihadapi.

Model pembelajaran inkuiri terbimbing adalah usaha menghidupkan rasa ingin tahu. Model inkuiri terbimbing melibatkan semua keahlian siswa guna menganalisis secara kritis, sistematis, logis, serta analitis hal ini menyebabkan siswa lebih aktif melakukan eksperimen untuk memecahkan permasalahan (Trianto, 2010). Model pembelajaran inkuiri terbimbing yaitu proses pembelajaran dengan melibatkan mental dan fisik dengan melakukan observasi untuk menemukan dan mencari jawaban pertanyaan berupa informasi ilmiah untuk memecahkan permasalahan yang sudah dirumuskan. Model ini menjadikan siswa menjadi cerdas, kritis, dan memiliki wawasan yang luas (Hajrin et al., 2019).

Berdasarkan penjelasan model inkuiri terbimbing dapat disimpulkan bahwa inkuiri terbimbing adalah model yang menggabungkan informasi relevan. Siswa mampu menganalisis secara logis melalui eksperimen. Peran guru dalam pembelajaran ini yaitu membimbing siswa untuk menemukan dan mencari jawaban sendiri berdasarkan permasalahan yang diberikan. Pada pembelajaran ini memusatkan siswa dan guru hanya membimbing sehingga siswa mampu untuk memahami konsep secara baik.

Langkah-langkah dalam pembelajaran inkuiri terbimbing yaitu:

1. Orientasi, yaitu pada proses pembelajaran guru memusatkan siswa demi membangkitkan kemampuan berpikir siswa untuk memecahkan permasalahan.

2. Merumuskan masalah, yaitu siswa membuat rumusan masalah mengenai peristiwa yang telah disajikan oleh guru dengan konsep-konsep yang telah dimiliki sebelumnya.

3. Membuat hipotesis, yaitu siswa mampu membuat jawaban dari permasalahan yang dibuat dari konsep yang telah dipelajari secara rasional.
4. Mengumpulkan data, yaitu siswa bereksperimen untuk menguji hipotesis yang dibuat sebelumnya.

5. Menguji hipotesis, yaitu siswa menelaah hipotesis yang dibuat sebelumnya dengan hasil eksperimen yang telah dilakukan.

6. Melakukan kesimpulan, yaitu berdasarkan penemuan data dan uji hipotesis maka siswa mampu menjelaskan hasil yang di dapat diperkuat dengan uji literatur secara akurat (Sanjaya, 2008).

Berdasarkan PISA, upaya program pendidikan di negara berkembang salah satunya di Indonesia pada tahun 2018, hasil skor Indonesia pada pelajaran sains menduduki peringkat 71 dari 79 negara. Data tersebut menyatakan bahwa keterampilan berpikir di Indonesia masih kurang untuk siswa dalam menyelesaikan soal analisis, evaluasi, kreasi, logika, serta penalaran (Kurniati et al., 2016).

Data PISA 2018, kebutuhan pendidikan di Indonesia saat ini yaitu menganalisis dan menalar permasalahan yang ada di lingkungan. Berdasarkan permasalahan tersebut menunjukkan bahwa kemampuan berpikir kritis siswa sangat dibutuhkan. Hasil observasi Rinawati, Abdurrahman, dan Jalmo (2016) menunjukkan ketika proses pembelajaran IPA, siswa kesulitan mengaitkan konsep satu dengan konsep lain, 75\% siswa kurang ditekankan untuk berpikir kritis secara mandiri oleh guru dan sebanyak $78 \%$ pembelajaran IPA masih didominasi guru.

Diperkuat dengan penelitian dari Winoto \& Prasetyo (2020) di SMP Kabupaten Brebes kemampuan berpikir kritis siswa masih tergolong rendah. Jumlah siswa yang mempunyai keahlian berpikir kritis baik tidak lebih dari $30 \%$. Pada nyatanya siswa cuma menerima penjelasan yang diberikan oleh guru dan cenderung pasif sekitar $70 \%$ sampai $80 \%$. Priyadi et al. (2018) melaporkan jika rendahnya kemahiran berpikir kritis yaitu siswa merasa kesulitan, miskonsepsi, kurangnya pemahaman siswa dan pengetahuan yang terpotong-potong.

Permasalahan rendahnya kemampuan berpikir kritis perlu dicarikan solusi agar pembelajaran mampu memberi hasil yang optimal dan mampu meningkatkan keterampilan siswa menjadi lebih kritis. Pemecahan yang tepat yaitu memakai model pembelajaran yang membagikan peluang pada 
siswa guna keikutsertaan dalam proses pembelajaran serta melatih kemampuan siswa berpikir secara kritis. Model pembelajaran tersebut menggunakan model pembelajaran inkuiri terbimbing (Winoto \& Prasetyo, 2020).

Kemampuan berpikir kritis adalah kemampuan analitis dan evaluatif siswa dalam memperoleh informasi dan pengalaman melalui proses pembelajaran sesuai dengan indikator yaitu memberikan penjelasan dasar, membangun keterampilan dasar, menyimpulkan, membuat penjelasan lebih lanjut, dan membuat strategi serta taktik (Firdaus \& Wilujeng, 2018).

Kemampuan berpikir kritis merupakan teknik disiplin ilmu dengan cakap, terampil, dapat pengaplikasiannya, pengkajian, mensintesis, dan mengevaluasi hasil eksperimen, penalaran hingga mampu mengkomunikasikan bahwa pemikirannya sebagai patokan keyakinan untuk melakukan suatu tindakan (Larsson, 2017). Kemampuan berpikir kritis yaitu kemampuan berpikir dengan baik, logik, terbuka, serta mampu mengikuti zaman untuk membuat pemikiran yang baru yang efisien (Kun, 2013).

Pada proses pembelajaran, kemampuan berpikir siswa dituntut guna berpikir dengan baik, terbuka, logis, dan mampu beradaptasi dengan perkembangan zaman sehingga siswa mampu untuk membuat terobosan baru demi memajukan kecerdasan bangsa (Kun, 2013). Keterampilan berpikir kritis siswa dalam mengemukakan pertanyaan yang sinkron dengan permasalahan, mampu menyatukan informasi yang bermakna, mampu bertindak efisien, kreatif serta mampu mengambil kesimpulan yang dapat diuji kebenarannya (Kun, 2013). Sejalan dengan (Facione, 2020) kemampuan yang menggunakan berpikir secara kritis adalah daya untuk menetapkan sesuatu yang mewujudkan interpretasi, telaah, evaluasi, dan simpulan menggunakan petunjuk, konsepsi, metodologi, maupun pertimbangan kontekstual yang menjadi dasar pembuatan simpulan (Winoto \& Prasetyo, 2020).

Dari beberapa pendapat dapat disimpulkan bahwa kemampuan berpikir kritis ketika siswa mampu berpikir logis, mampu memilih dan memilah informasi yang valid dan relevan dan hasil pemikirannya mengikuti zaman.
Keahlian berpikir kritis bagi Ennis (1993) terdapat lima, memberi uraian sederhana, memandirikan siswa untuk membuat keahlian dasar, menyimpulkan, memberi penjelasan lebih lanjut serta mengendalikan strategi dan taktik. Kompetensi dan indikator kemampuan berpikir kritis sebagai berikut.

1. Kompetensi memberikan penjelasan dasar memiliki indikator siswa dapat memfokuskan pertanyaan yang ingin dibuat, menganalisis argumen, dan mampu bertanya, menjawab pertanyaan berupa klarifikasi dan membuat pertanyaan yang menantang.

2. Kompetensi membangun keterampilan yaitu memiliki indikator mempertimbangkan sumber dapat dipercaya atau tidak, siswa mampu mengobservasi dan mempertimbangan hasil observasi.

3. Kompetensi menyimpulkan yaitu memiliki indikator mendeduksi mempertimbangkan hasil observasi, menginduksi mempertimbangkan hasil induksi, dan membuat serta mengkaji nilai-nilai hasil pertimbangan.

4. Membut penjelasan lebih lanjut memiliki indikator siswa mampu mengidentifikasi istilah serta mempertimbangkan definisi dan mampu mengidentifikasi asumsi.

5. Strategi dan taktik memiliki dua indikator yaitu memutuskan suatu tindakan dan mampu berinteraksi dengan orang lain.

Pentingnya kemampuan berpikir kritis untuk siswa yaitu siswa akan mengamati keadaan yang ada disekelilingnya, membuat siswa bertanya dengan keadaan yang diamatinya sehingga siswa mampu merumuskan hipotesis, melakukan observasi, dan memberikan kesimpulan dari apa yang telah diamati dan diperoleh dari studi literatur. Berpikir kritis akan mengembangkan bakat siswa, melatih konsentrasi dan memfokuskan permasalahan serta berpikir analitis (Wahyuni, 2015)

Kemampuan berpikir kritis didasari oleh pembaharuan pengetahuan untuk menganalisis dan mengidentifikasi sebab akibat, mengkonstruk ide dan mengevaluasi pada pembelajaran IPA (Marudut et al., 2020). IPA ialah ilmu pengetahuan yang mempelajari indikasi alam berupa fakta, konsep, prinsip dan 
hukum yang telah berbukti kebenarannya (Wisudawati, 2015). Keempat unsur dalam proses pembelajaran IPA membuat IPA menjadi utuh. Nyatanya saat ini pembelajaran IPA di SMP masih diajarkan untuk menghafal informasi sehingga siswa kurang memahami aplikasi dari informasi yang didapat. Perihal ini tidak sejalan dengan tujuan pendidikan IPA yang dapat mengaitkan aspek pengetahuan, keahlian, serta perilaku (Sanjaya, 2014).

Siswa yang mampu mengaplikasikan informasi dalam kehidupan nyata merupakan salah satu dari tercapainya target sains. Siswa yang berpikir secara kompleks tentang kemampuan berpikir kritis dan pemecahan masalah merupakan kebutuhan pembelajaran saat ini (Mufida Nofiana, Sajidan, 2016). Pada proses pembelajaran, kemampuan berpikir siswa dituntut guna berpikir dengan baik, terbuka, logis, dan mampu beradaptasi dengan perkembangan zaman sehingga siswa mampu untuk membuat terobosan baru demi memajukan kecerdasan bangsa (Kun, 2013). Keterampilan berpikir kritis siswa dalam mengemukakan pertanyaan yang sinkron dengan permasalahan, mampu menyatukan informasi yang bermakna, mampu bertindak efisien, kreatif serta mampu mengambil kesimpulan yang dapat diuji kebenarannya (Kun, 2013). Sejalan dengan (Facione, 2020) kemampuan yang menggunakan berpikir secara kritis adalah daya untuk menetapkan sesuatu yang mewujudkan interpretasi, telaah, evaluasi, dan simpulan menggunakan petunjuk, konsepsi, metodologi, maupun pertimbangan kontekstual yang menjadi dasar pembuatan simpulan (Winoto \& Prasetyo, 2020).

Berdasarkan hasil observasi dari wawancara pada guru dan siswa didapat bahwa daya berpikir kritis siswa kelas VIII di SMP Negeri 4 Mojokerto untuk pembelajaran IPA masih kurang mampu guna menghubungkan dua konsep yang berbeda dalam menyelaraskan untuk memecahkan permasalahan (Kurniati et al., 2016). Guru menjelaskan pembelajaran di depan pada proses pembelajaran dan siswa mencermati uraian yang dijelaskan guru, hal ini menjadikan siswa stagnan dan kesulitan untuk berpikir kritis. Indikator yang wajib untuk memenuhi berpikir kritis yang lebih baik yaitu siswa memberikan deskripsi dasar, membangun kefasihan dasar, menyimpulkan, membuat penjelasan lebih lanjut serta prosedur dan taktik (Ennis, 1993).

Permasalahan rendahnya kemampuan berpikir kritis perlu dicarikan solusi agar pembelajaran mampu memberi hasil yang optimal dan mampu meningkatkan keterampilan siswa menjadi lebih kritis. Pemecahan yang tepat yaitu memakai model pembelajaran yang membagikan peluang pada siswa guna keikutsertaan dalam proses pembelajaran serta melatih kemampuan siswa berpikir secara kritis. Model pembelajaran tersebut menggunakan model pembelajaran inkuiri terbimbing (Winoto \& Prasetyo, 2020).

\section{Metode}

Penelitian yang dilakukan bersifat deskriptif. Metode yang digunakan yaitu wawancara dan studi literatur untuk mencari solusi kemampuan berpikir kritis yang rendah siswa di SMP Negeri 4 Mojokerto. Instrumen yang dipakai dalam penelitian adalah uji wawancara guru IPA dan siswa kelas VIII SMP Negeri 4 Mojokerto.

\section{Hasil dan Pembahasan Hasil}

Penelitian yang telah dilakukan berdasarkan wawancara guru IPA SMP Negeri 4 Mojokerto membutuhkan penyempurnaan model pembelajaran yang butuhkan siswa. Menurut guru IPA kelas VIII, kemampuan siswa untuk berpikir kritis rendah, dibuktikan pada respon siswa jika diberi pertanyaan. Siswa pasif dalam menjawab pertanyaa yang diberikan oleh guru, ketika dijelaskan dan diberikan waktu untuk bertanya, siswa hanya diam saja. Menurut guru ketika diberi pertanyaan siswa memberi tanggapan yang sesuai dengan penjelasan dibuku tanpa berpikir lebih dalam hal menganalisis fenomena yang di berikan.

Guru sudah mengusahakan untuk mengganti model yang telah dilakukan dengan mempraktikkan model discovery learning. discovery learning yang mengajarkan siswa untuk memahami dan menemukan konsep (Astuti et al., 2018). Nyataannya aplikasi model tersebut untuk menyampaikan materi masih berpusat pada guru sehingga siswa tetap pasif.

Menurut siswa berdasarkan hasil wawancara, pembelajaran IPA terasa sulit 
untuk dipahami. Siswa beranggapan bahwa IPA memiliki banyak rumus matematis, siswa kurang memahami dan merasa kesukaran menghubungkan berbagai konsep menjadi satu kesatuan sehingga menyebabkan siswa memiliki kemampuan berpikir kritis yang rendah. Salah satu faktor yang menghambat kemampuan berpikir kritis salah satunya siswa yang pasif yang memberi tanggapan yang tersedia di buku. Selain itu siswa akan merasa bosan pada proses pembelajaran. Tanggapan siswa tersebut menyebabkan tujuan dari pembelajaran kurang tercapai. Upaya untuk mencapai tujuan pembelajaran dibutuhkan penerapan model pembelajaran maupun penggunaan media dengan tepat (Arviansyah et al., 2016).

\section{Pembahasan}

Berdasarkan hasil riset yang telah dilakukan di SMP Negeri 4 Kota Mojokerto. Permasalahan rendahnya kemampuan berpikir kritis perlu dicarikan solusi agar pembelajaran mampu memberi hasil yang optimal dan mampu meningkatkan keterampilan siswa menjadi lebih kritis. Pemecahan yang tepat yaitu memakai model pembelajaran yang membagikan peluang pada siswa guna keikutsertaan dalam proses pembelajaran serta melatih kemampuan siswa berpikir secara kritis.

\section{a. Model Inkuiri Terbimbing}

Model pembelajaran inkuiri terbimbing menawarkan pembelajaran menggunakan penyelidikan yang terintegrasi, terencana, dan guru membimbing siswa untuk mengembangkan pemahaman yang lebih baik berkenaan dengan pengetahuan konsep dan keterampilan yang memiliki manfaat dalam kehidupan sehari-hari (Firdaus \& Wilujeng, 2018). Model inkuiri terbimbing meletakkan siswa sebagai subjek pembelajaran. Siswa ikut serta dalam keaktifan pada proses pembelajaran serta sanggup tingkatkan keahlian dalam berpikir dengan kritis (Amijaya et al., 2018). Pembelajaran IPA menggunakan model inkuiri terbimbing memungkinkan siswa untuk menemukan dan memberikan pengalaman dalam menemukan solusi dari kasus yang sering ditemui dalam kehidupan nyata (Piaget dalam Sofan \& Iif, 2010).

$$
\text { Menurut Dewi (2016) Siswa }
$$
menyusun prosedur sendiri untuk melakukannya. Inkuiri terbimbing digunakan untuk pemahaman konseptual dan keterampilan siswa, mengembangkan kreativitas, dan memahami pengertian. Sejalan dengan pendapat (Rustaman, 2005) bahwa inkuiri terbimbing lebih menekankan dalam diskusi.

Model inkuiri terbimbing ialah model pembelajaran yang mengaitkan semua pemikiran siswa untuk menganalisis fenomena secara terstruktur, kritis, valid, hingga siswa dapat menguraikan penemuan yang didapat (Trianto, 2010). Menyelesaikan permasalahan membutuhkan kemampuan berpikir siswa salah satunya yaitu kemampuan berpikir kritis.

Pembelajaran memanfaatkan model inkuiri terbimbing memiliki kelebihan yaitu:

1. Mampu membangun potensi yang dimiliki oleh siswa,

2. Memahami inti dari materi pembelajaran beserta pengembangannya,

3. Mampu mengembangkan bakat siswa, serta pembelajaran berpusat pada siswa (Kholida et al., 2015).

4. Memotivasi siswa untuk berpikir dalam merumuskan hipotesis (Jundu et al., 2020).

Sintaks model pembelajaran inkuiri terbimbing bagi Sanjaya (2008) dapat dilihat pada tabel 1.

Tabel 1 Sintaks Pembelajaran Inkuiri Terbimbing

\begin{tabular}{|c|c|c|}
\hline No & Sintaks & Keterangan \\
\hline 1 & Orientasi & 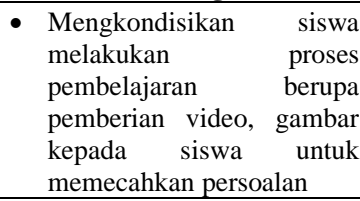 \\
\hline 2 & $\begin{array}{l}\text { Merumuskan } \\
\text { masalah }\end{array}$ & $\begin{array}{l}\text { - Merumuskan permasalahan } \\
\text { yang diberikan berdasarkan } \\
\text { pengetahuan yang telah } \\
\text { dimiliki }\end{array}$ \\
\hline 3 & $\begin{array}{l}\text { Merumuskan } \\
\text { hipotesis }\end{array}$ & $\begin{array}{ll}\text { - } & \text { Merumuskan jawaban } \\
\text { sementara sesuai dengan } \\
\text { literatur yang telah dimiliki }\end{array}$ \\
\hline 4 & $\begin{array}{l}\text { Mengumpulkan } \\
\text { data }\end{array}$ & $\begin{array}{l}\text { - Menganalisis informasi } \\
\text { secara logis dan rasional } \\
\text { berdasarkan eksperimen } \\
\text { dan uji literatur }\end{array}$ \\
\hline 5 & Menguji hipotesis & $\begin{array}{l}\text { - Menetapkan jawaban yang } \\
\text { akurat berdasarkan data }\end{array}$ \\
\hline 6 & $\begin{array}{l}\text { Merumuskan } \\
\text { kesimpulan }\end{array}$ & 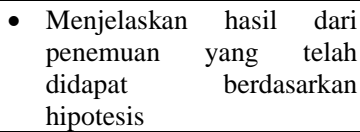 \\
\hline
\end{tabular}

b. Interaksi Model Pembelajaran Inkuiri Terbimbing terhadap Kemampuan Berpikir Kritis 
Berikut interaksi antara model pembelajaran inkuiri terbimbing dengan kemampuan berpikir kritis siswa.

1. Pada tahapan orientasi siswa diminta untuk mengamati berupa demonstrasi, video, dan gambar yang telah dilakukan maupun ditayangkan oleh guru. Hal ini akan menarik perhatian siswa untuk memperhatikan, berpikir serta menuliskan pernyataan apa yang telah dilihat berdasarkan tayangan maupun demonstrasi. Pernyataan yang telah dibuat akan dipresentasikan kepada teman-teman sejawatnya. Orientasi sejalan dengan indikator kemampuan berpikir kritis pada memberikan penjelasan dasar. Siswa memberi argumen berdasarkan demonstransi maupun tayangan berupa gambar atau video yang telah diberikan oleh guru. Siswa berpikir untuk menganalisis fenomena yang terjadi kemudian siswa membuat pernyataan.

2. Tahapan kedua yaitu merumuskan masalah. Siswa membuat pertanyaan berdasarkan apa yang telah dilihat dan dipahami dari demonstrasi, gambar maupun video. Guru membimbing siswa untuk merumuskan permasalahan sesuai dengan dengan pengetahuan yang selaras dengan literatur. Bimbingan guru untuk membuat rumusan masalah sangat dibutuhkan agar sesuai dengan tujuan pembelajaran yang ingin dicapai. Tahap merumuskan masalah pada sintaks inkuiri terbimbing berkolerasi dengan indikator kemampuan berpikir kritis. Siswa memberikan penjelasan dasar berupa memfokuskan pertanyaan agar siswa mampu merumuskan masalah. Siswa akan berpikir untuk membuat pertanyaan sesuai dengan tujuan yang akan dicapai.

3. Tahap ketiga yaitu Merumuskan hipotesis. Siswa membuat dugaan sementara dari rumusan masalah yang telah dibuat. Dugaan tersebut harus berdasarkan literartur dan bimbingan guru. Merumuskan hipotesis sejalan dengan indikator kemampuan berpikir kritis pada memberikan penjelasan dasar dan membangun keterampilan dasar. Penjelasan dasar berupa penjelasan dari pertanyaan yang telah dibuat. Membangun keterampilan dasar dengan mempertimbangkan sumber yang relevan dan dapat dipertanggung jawabkan hipotesis yang telah dirumuskan.

4. Pada tahapan keempat yaitu merumuskan data. Data yang didapat berdasarkan eksperimen. Eksperimen dilakukan untuk menguji hipotesis yang telah dibuat. Setelah melakukan eksperimen, siswa mencari informasi dengan studi literatur apakah eksperimen yang dilakukan sesuai dengan literatur atau tidak. Merumuskan data sejalan dengan indikator berpikir kritis pada membangun keterampilan dasar. Korelasi kompetensi membangun keterampilan dasar pada observasi hasil. Siswa melakukan eksperimen untuk menemukan hasil yang diperlukan dalam proses pembelajaran.

5. Inkuiri terbimbing pada tahap menguji hipotesis yaitu siswa menelaah ulang hipotesis yang telah dibuat. Menentukan jawaban dari hipotesis yang telah dibuat telah sesuai atau tidak. Ketika menguji hipotesis, siswa mengkaji ulang hipotesis yang sesuai dengan percobaan dan studi literatur yang telah didapat. Tahapan kelima ini sejalan dengan indikator kemampuan berpikir kritis. Menguji hipotesis akan mengkaji ulang dengan pertimbangan uji literatur dan percobaan yang telah dilakukan. Hipotesis yang dibuat dikaji ulang untuk memastikan pengetahuan yang telah dikemukakan dan literatur logis atau tidak.

6. Pada tahapan terakhir yaitu merumuskan kesimpulan. Kesimpulan akan dibuat setelah melakukan pengujian hipotesis. Tahapan ini guru bersama siswa untuk menjabarkan informasi yang sesuai agar mendapatkan keputusan akhir yang akurat. Merumuskan kesimpulan sejalan dengan indikator kemampuan berpikir kritis. Siswa mengkaji hasil eksperimen dan studi literatur. Sebelum membuat kesimpulan siswa mengidentifikasi asumsi yang telah didapat apakah telah sesuai atau tidak hingga siswa mampu memutuskan suatu gagasan berupa kesimpulan.

Pelaksanaan model inkuiri terbimbing dengan sintaks, orientasi, merumuskan masalah, merumuskan hipotesis, mengumpulkan data, menguji hipotesis, dan merumuskan kesimpulan selaras dengan 
sintaks indikator berpikir kritis dengan memberikan penjelasan dasar, membangun keterampilan dasar, menyimpulkan, membuat penjelasan lebih lanjut serta membuat strategi dan taktik. Pada proses inkuiri siswa ditekankan untuk berpikir mampu tingkatkan kompotensi pemahaman yang kritis seperti disajikan pada gambar 1

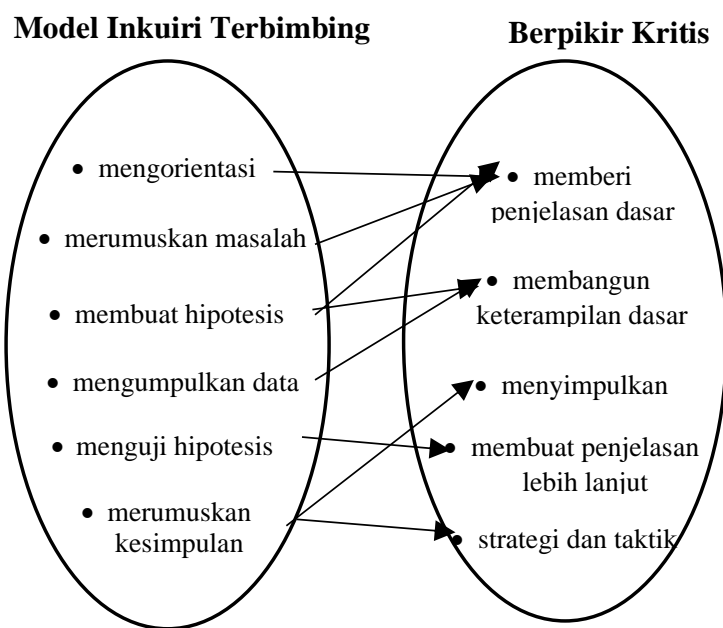

Gambar 1 Keterkaitan Model Pembelajaran Inkuiri Terbimbing terhadap Kemampuan Berpikir Kritis

Penjelasan diatas diperkuat oleh (Ajwar Muhamad, Baskoro Adi Prayitno, 2015) pembelajaran inkuiri dapat meningkatkan memampuan berpikir kritis. Ditandai dengan siswa mampu membuat pertimbangan serta membuat keputusan dengan cara, metode belajar untuk memahami dan bertanggung jawab atas konsep yang telah dipelajari. Sejalan dengan Firdaus \& Wilujeng, (2018) melalui lembar kerja siswa yang berbasis inkuiri terbimbing siswa memunculkan kemampuan berpikir kritis dibuktikan dengan siswa lebih cepat dalam melakukan penyelidikan.

Siswa dengan kemampuan berpikir kritis cenderung mampu mengkaji ulang pendapat yang diberikan berdasarkan pengetahuan yang sudah ia miliki. Hal ini sesuai dengan hasil penelitian Syahmani (2016), bahwa seorang yang berpikir kritis akan mengkaji ulang apakah keyakinan dan pengetahuan yang dimiliki atau dikemukakan orang lain logis atau tidak. Siswa juga cenderung dapat menunjukkan solusi pemecahan masalah yang paling efektif menurutnya di antara solusisolusi yang diberikan. Murti (2009) menjelaskan ciri orang yang memiliki berpikir kritis tinggi yaitu dapat menarik kesimpulan dan solusi dengan alasan yang kuat dan bukti yang kuat, serta mengujinya dengan menggunakan kriteria tertentu.

\section{Kesimpulan dan Rekomendasi}

Inkuiri terbimbing merupakan adalah model yang menggabungkan informasi relevan. Siswa mampu menganalisis secara logis melalui eksperimen. Peran guru dalam pembelajaran ini yaitu membimbing siswa untuk menemukan dan mencari jawaban sendiri berdasarkan permasalahan yang diberikan. Pada pembelajaran ini memusatkan siswa dan guru hanya membimbing sehingga siswa mampu untuk memahami konsep secara baik.

Kemampuan berpikir kritis siswa yaitu ketika siswa mampu berpikir logis, mampu memilih dan memilah informasi yang valid dan relevan dan hasil pemikirannya mengikuti zaman.

Bersumber pada hasil serta ulasan yang sudah dipaparkan, solusi yang efisien menanggulangi rendahnya kemampuan berpikir kritis siswa kelas VIII SMP Negeri 4 Mojokerto diperlukan model pembelajaran inkuiri terbimbing. Model inkuiri terbimbing dalam pembelajaran IPA sanggup memfasilitasi guna melakukan penyelidikan ilmiah hingga aktif dalam proses belajar mengajar, sanggup membuat ketetapan yang dapat dipercayai. Keputusan yang didapat harus memiliki fakta, konsepsi, teknik, maupun peninjauan konteks yang menjadi dasar pembuatan keputusan sampai mampu melatih kemampuan memikirkan permasalahan dengan kritis.

Bersumber pada penelitian yang sudah dilangsungkan, butuh penelitian lebih lanjut pada model pembelajaran inkuiri terbimbing terhadap kemampuan berpikir kritis di SMP Negeri 4 Mojokerto. Kepada periset yang hendak melaksanakan penelitian yang sejenis hendak mencermati waktu supaya sanggup memenajemen waktu dengan baik sehingga proses belajar mengajar berjalan efisien dan efektif.

\section{DAFTAR RUJUKAN}

Amri, Sofan dan Lif Khoiru Ahmadi. (2010). Konstruksi Pengembangan Pembelajaran. 
Jakarta: Prestasi Pustaka.

Ajwar Muhamad, Baskoro Adi Prayitno, W. S. (2015). Pengaruh Pembelajaran Inkuiri Terbimbing Dan Inkuiri Bebas Termodifikasi Terhadap Prestasi Belajar Ditinjau Dari Berpikir Kritis Dan Kedisiplinan Belajar Siswa Kelas X Mia Sma Negeri 8 Surakarta Tahun Pelajaran 2014/2015. Inkuiri, 4(3), 1-9.

Amijaya, L. S., Ramdani, A., \& Merta, I. W. (2018). Pengaruh Pembelajaran Inkuiri Terbimbing terhadap Hasil Belajar dan Kemampuan Berpikir Kritis Peserta Didik. J. Pijar MIPA, 13(2), 94-99.

Annafi, N., Ashadi, \& Mulyani, S. (2015). Pengembangan Lembar Kegiatan Peserta Didik Berbasis Inkuiri Terbimbing pada Materi Termokimia Kelas XI SMA/MA. Jurnal Inkuiri, 4(3), 21-28.

Arviansyah, R., Indrawati, I., \& Harijanto, A. (2016). Pengaruh Model Pembelajaran Guided Inquiry Disertai LKS Audiovisual Terhadap Aktivitas Dan Hasil Belajar IPA Siswa Di SMP. Jurnal Pembelajaran Fisika, 4(4), 308-314-314.

Astuti, T. I., Idrus, I., \& Yennita, Y. (2018). Penerapan Model Pembelajaran Discovery Learning Untuk Meningkatkan Hasil Belajar pada Materi Biologi Siswa SMP. Diklabio: Jurnal Pendidikan Dan Pembelajaran Biologi, 2(1), 5-9.

Damhuri, D. (2020). Penerapan Model Pembelajaran Inkuiri Terstruktur untuk Meningkatkan Hasil Belajar Peserta Didik Kelas IX MTsN 1 Lebong. Jurnal Pendidikan Dan Pembelajaran Biologi, 4(1), 47-54.

Dewi, P. S. (2016). Perspektif Guru Sebagai Implementasi Pembelajaran Inkuiri Terbuka dan Inkuiri Terbimbing terhadap Sikap Ilmiah dalam Pembelajaran Sains. Tadris: Jurnal Keguruan Dan Ilmu Tarbiyah, 1(2), 179.

Ennis, R. H. (1993). Critical thinking assessment. Theory Into Practice, 32(3), 179-186. https://doi.org/10.1080/00405849309543 594

Facione, P. A. (2020). Critical Thinking: What It Is and Why It Counts 2020 Update. In e-conversion - Proposal for a Cluster of Excellence: Vol. XXVIII (Issue 1).

Firdaus, M., \& Wilujeng, I. (2018). Pengembangan LKPD Inkuiri Terbimbing untuk Meningkatkan Keterampilan Berpikir Kritis dan Hasil Belajar Peserta Didik. Jurnal Inovasi Pendidikan IPA, 4(1), 26-40.

Hajrin, M., Sadia, I. W., \& Gunandi, I. G. A. (2019). Pengaruh Model Pembelajaran Inkuiri Terbimbing terhadap Keterampilan Berpikir Kritis Siswa pada Pembelajaran Fisika Kelas X IPA SMA Negeri. Jurnal Pendidikan Fisika Undiksha, 9(1), 65.

Jundu, R., Tuwa, P. H., \& Seliman, R. (2020). Hasil Belajar IPA Siswa SD di Daerah Tertinggal dengan Penerapan Model Pembelajaran Inkuiri Terbimbing. Scholaria: Jurnal Pendidikan Dan Kebudayaan, 10(2), 103-111.

Kholida, S. I., Studi, P., Fisika, P., \& Madura, U. I. (2015). Efektivitas Penerapan Model Inkuiri Terhadap Peningkatan Prestasi Belajar Siswa Sub Pokok Bahasan Cermin Datar. Jurnal Pemikiran Penelitian Pendidikan Dan Sains, 3(6).

Kun, P. Z. (2013). Potret Pembelajaran Fisika Berbasis Empat Pilar Pendidikan di SMA. PROSIDING : Seminar Nasional Fisika Dan Pendidikan Fisika, 2(1), 246-256.

Kurniati, D., Harimukti, R., \& Jamil, N. A. (2016). Kemampuan Berpikir Tingkat Tinggi Siswa SMP di Kabupaten Jember dalam Menyelesaikan Soal Berstandar PISA. Jurnal Penelitian Dan Evaluasi Pendidikan, 20(2), 142-155.

Larsson, K. (2017). Understanding and teaching critical thinking-A new approach. International Journal of Educational Research, 84(May), 32-42. 
Marudut, M. R. H., Bachtiar, I. G., Kadir, K., \& Iasha, V. (2020). Peningkatan Kemampuan Berpikir Kritis dalam Pembelajaran IPA melalui Pendekatan Keterampilan Proses. Jurnal Basicedu, 4(3), 577-585.

Mufida Nofiana, Sajidan, dan P. (2016). Pengembangan Instrumen Evaluasi Higher Order Thinking Skills Pada Materi Kingdom Plantae. J. Pedagogi Hayati, 01(01), 46-53.

Murti, B. (2009). Berpikir Kritis. Makalah, Seri Kuliah Blok Budaya Ilmiah, Institute for Health Economic and Policy Studies (IHEPS)/ Bagian Ilmu Kesehatan Masyarakat, Fakultas Kedokteran, Universitas Sebelas Maret, 1, 1-476.

Priyadi, R., Mustajab, A., Tatsar, M. Z., \& Kusairi, S. (2018). Analisis Kemampuan Berpikir Kritis Siswa SMA Kelas X MIPA dalam Pembelajaran Fisika. JPFT (Jurnal Pendidikan Fisika Tadulako Online), 6(1), 53.

Rinawati, Abdurrahman, \& Jalmo, T. (2016). Pengaruh Problem Based Learning terhadap Keterampilan Berpikir Kritis Siswa. Jurnal Pendidikan Progresif, VI(2), 147.

Rustaman, N. Y. (2005). Perkembangan penelitian pembelajaran inkuiri dalam pendidikan sains development of research in inquiry science teaching. Seminar Nasional II, 22-23.

Syahmani, S. (2016). Model Group Investigation Dan Induktif Sebagai Alternatif Mengembangkan Keterampilan Proses Sains Dan Berpikir Siswa. Quantum: Jurnal Inovasi Pendidikan Sains, 4(1), 59-70.

Syamsu, F. D. (2017). Pengembangan Penuntun Praktikum IPA Berbasis Inkuiri Terbimbing Untuk Siswa SMP Siswa Kelas VII Semester Genap. BIOnatural, 4(2), 13-27.
Trianto. 2010. Model Pembelajaran Terpadu, Konsep, Strategi dan Implementasinya dalam KTSP. Jakarta: Bumi Aksara.

Wahyuni, S. (2015). Pengembangan Petunjuk Praktikum IPA Untuk Meningkatkan Kemampuan Berpikir Kritis Siswa SMP. Jurnal Pengajaran Matematika Dan Ilmu Pengetahuan Alam, 6(1), 196.

Winoto, Y. C., \& Prasetyo, T. (2020). Efektivitas Model Problem Based Learning Dan Discovery Learning Terhadap Kemampuan Berpikir Kritis Siswa Sekolah Dasar. Jurnal Basicedu, 4(2), 228-238.

Wisudawati, A. \& Sulistyowati, E. 2015. Metodologi Pembelajaran IPA. Jakarta: PT Bumi Perkasa. 